$\begin{array}{rr}\text { FIT(PPATOLOGI } & \text { Volume 9, Nomor 4, Agustus } 2013 \\ \text { I N D ON ES IA } & \text { Halaman 127-131 } \\ \text { ISSN: } 2339-2479 & \text { DOI: } 10.14692 / \text { jfi.9.4.127 }\end{array}$

TEMUAN PENYAKIT BARU

\title{
Tomato yellow leaf curl Kanchanaburi virus Penyebab Penyakit Mosaik Kuning pada Tanaman Terung di Jawa
}

\author{
Tomato yellow leaf curl Kanchanaburi virus Associated with \\ Yellow Mosaic Disease of Eggplant in Java
}

\author{
Tega Kintasari ${ }^{1}$, Dwi Wiyati Nurul Septariani ${ }^{1}$, Sri Sulandari ${ }^{2}$, Sri Hendrastuti Hidayat ${ }^{*}$ \\ ${ }^{1}$ Institut Pertanian Bogor, Bogor 16680 \\ ${ }^{2}$ Universitas Gadjah Mada, Yogyakarta 55281
}

\begin{abstract}
ABSTRAK
Gejala daun menguning dan mosaik kuning ditemukan pada tanaman terung (Solanum melongena) di daerah Bogor, Bandung, Pati, Rembang, dan Bantul pada awal 2013. Deteksi virus dengan metode polymerase chain reaction dilakukan menggunakan DNA total yang diisolasi dari daun tanaman bergejala dan primer universal Begomovirus, SPG1/SPG2. Amplikon dengan ukuran yang diharapkan ( $\sim 900 \mathrm{pb})$ berhasil diperoleh dari kelima sampel daun yang bergejala dan mengindikasi adanya infeksi Begomovirus. Hasil perunutan nukleotida pita DNA hasil amplifikasi tersebut selanjutnya digunakan untuk analisis menggunakan basic local alignment search tool. Identifikasi berdasarkan analisis perunutan nukleotida menunjukkan bahwa kelima isolat Begomovirus tersebut berkerabat dekat (98.8\%) dengan Tomato yellow leaf curl Kanchanaburi virus (TYLCKaV) asal Thailand. Hasil deteksi dan identifikasi ini merupakan laporan pertama di Indonesia mengenai TYLCKaV yang menginfeksi tanaman terung.
\end{abstract}

Kata kunci: Begomovirus, homologi, perunutan nukleotida, primer universal

\begin{abstract}
Yellow and yellow mosaic symptoms was observed on eggplant (Solanum melongena) around Bogor, Bandung, Pati, Rembang, and Bantul during a survey in early 2013. Polymerase chain reaction based detection was carried out using total DNA isolated from symptomatic leaf samples and a pair of Begomovirus-universal primers, SPG1/SPG2. The expected size ( 900 bp) amplicon was detected from all five symptomatic samples, indicating the presence of Begomovirus infection. Each amplicon was sequenced followed by basic local alignment search tool analysis. It was revealed that the sequence had the highest homology (98.8\%) with Tomato yellow leaf curl Kanchanaburi virus (TYLCKaV) sequence. This is the first report on TYLCKaV infection on eggplant in Indonesia.
\end{abstract}

Key words: Begomovirus, homology, nucleotide sequences, universal primer

*Alamat penulis korespondensi: Departemen Proteksi Tanaman, Fakultas Pertanian, Institut Pertanian Bogor, Kampus Darmaga, Jalan Kamper, Bogor 16680

Tel: 0251 8629364, Faks:0251 8629362, Surel: srihendrastutihidayat@gmail.com 
Terung (Solanum melongena) merupakan tanaman sayur-sayuran yang dapat ditemukan tumbuh di daerah tropik maupun subtropik, tergolong tanaman yang adaptif dan mudah ditanam, serta dapat tumbuh sepanjang tahun. Terung hampir tumbuh di semua wilayah Indonesia baik di daerah dataran rendah maupun dataran tinggi, walaupun lebih banyak dibudidayakan di dataran rendah. Pada awal tahun 2013 ditemukan gejala daun menguning dan mosaik kuning pada tanaman terung di beberapa daerah di Jawa Barat (Bogor dan Bandung), Jawa Tengah (Pati dan Blora), dan Daerah Istimewa Yogyakarta (Bantul). Gejala menguning ditunjukkan oleh perubahan warna lamina daun dari hijau menjadi kuning cerah atau kuning pucat, tetapi tulang daun tetap berwarna hijau (Gambar 1a). Gejala mosaik kuning pada daun berupa perbedaan warna yang sangat mencolok pada daun, yakni kuning tua dan hijau tua (Gambar 1b). Pada gejala daun menguning maupun mosaik kuning tidak terjadi perubahan ukuran dan bentuk daun, gejala-gejala tersebut terutama ditemukan pada daun-daun muda. Umumnya tanaman yang menunjukkan gejala tidak menghasilkan buah. Beberapa tanaman yang menunjukkan gejala tetap menghasilkan buah, tetapi buah yang dihasilkannya memiliki ukuran yang lebih kecil dibandingkan dengan buah yang dihasilkan oleh tanaman sehat. Gejala menguning dan mosaik kuning ditemukan di Bogor, Bandung, Pati, Blora, dan Bantul dengan insidensi penyakit berturut-turut 6.3, 21, 9.2, 5.1, dan 30\%.
Green et al. (2003) melaporkan gejala mosaik kuning pada tanaman terung di Provinsi Kanchanaburi, Thailand disebabkan oleh Tomato yellow leaf curl virus (TYLCV), anggota Begomovirus, famili Geminiviridae. Penyakit pada terung dengan gejala yang sama dilaporkan juga terjadi di daerah Nagpur, Central India pada tahun 2009-2010. Deteksi dengan metode polymerase chain reaction (PCR) berhasil mengidentifikasi penyebab penyakit yang sangat parah tersebut ialah Tomato leaf curl New Delhi virus (ToLCNDV), salah satu anggota Begomovirus (Pratap et al. 2011). Berdasarkan laporan tersebut dan diperkuat dengan karakteristik gejala khas infeksi Begomovirus yang ditemukan, telah dilakukan deteksi untuk memastikan Begomovirus sebagai penyebab gejala mosaik kuning pada terung di Jawa.

Ekstraksi DNA total dari daun yang menunjukkan gejala dilakukan menggunakan metode CTAB (Doyle dan Doyle 1999). DNA total hasil ektraksi kemudian digunakan untuk amplifikasi pita DNA spesifik Begomovirus dengan primer universal SPG1 (5'-CCCCKGTGCGWRAATCCAT-3') dan SPG2 (5'-ATCCVAAYWTYCAGGGAGCT AA-3') (Li et al. 2004). Komposisi bahan dalam reaksi amplifikasi ialah 14.5-17.3 $\mu \mathrm{L}$ $\mathrm{H}_{2} \mathrm{O}, 2.5 \mu \mathrm{L}$ bufer $10 \mathrm{x}$ yang mengandung $\mathrm{Mg}^{2+}, 2 \mu \mathrm{L}$ dNTP $2.5 \mathrm{mM}, 1 \mu \mathrm{L}$ primer SPG1 dan SPG2 masing-masing, 0.2-0.3 $\mu \mathrm{L}$ Dream Taq Polymerase, dan $0.2 \mu \mathrm{L} \mathrm{MgCl} 25 \mathrm{mM}$. Program amplifikasi DNA adalah predenaturasi pada $94{ }^{\circ} \mathrm{C}$ selama 5 menit, dilanjutkan dengan

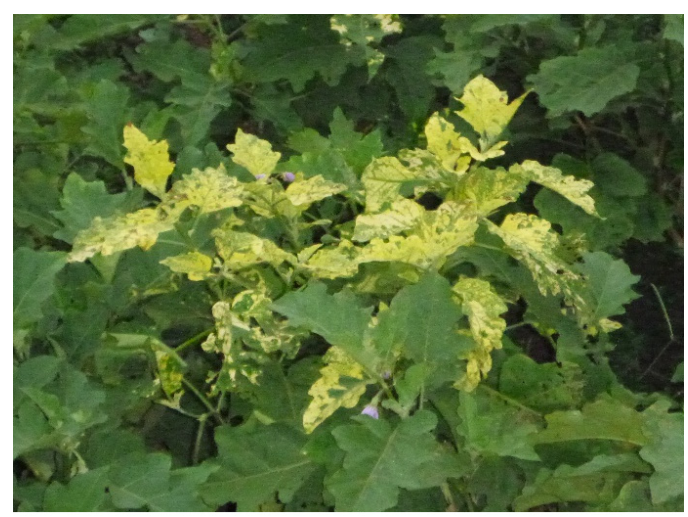

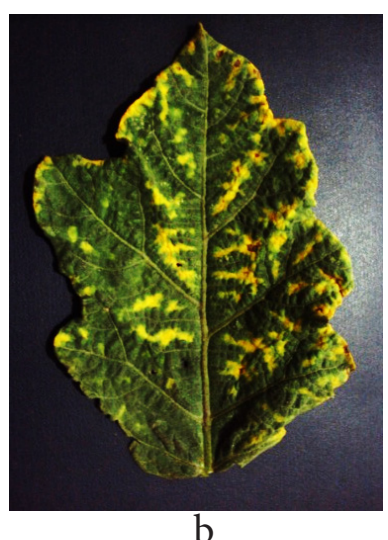

b

Gambar 1 Gejala infeksi virus pada tanaman terung di lapangan. a, Gejala menguning; b, Gejala mosaik kuning. 
30 siklus yang terdiri atas tahap denaturasi pada $94{ }^{\circ} \mathrm{C}$ selama 1 menit, penempelan primer pada $50{ }^{\circ} \mathrm{C}$ selama 1 menit, sintesis utas DNA pada $72{ }^{\circ} \mathrm{C}$ selama 1 menit, pemanjangan utas DNA pada $72{ }^{\circ} \mathrm{C}$ selama 7 menit, dan penyimpanan pada suhu $4{ }^{\circ} \mathrm{C}$ (Li et al. 2004). Pita DNA hasil amplifikasi divisualisasi pada $1 \%$ gel agarosa dalam $0.5 x$ bufer TBE (Tris-borate EDTA).

Pasangan primer SPG1/SPG2 berhasil mengamplifikasi pita DNA berukuran $\sim 900 \mathrm{pb}$ dari kelima sampel daun yang menunjukkan gejala menguning atau mosaik kuning (Gambar 2). Hasil deteksi ini membuktikan adanya infeksi Begomovirus pada tanaman terung tersebut. Pita DNA hasil amplifikasi kemudian digunakan untuk perunutan basa nukleotida dan selanjutnya basa nukleotida yang diperoleh digunakan untuk analisis genetik menggunakan program basic local alignment search tool (BLAST) (www.ncbi. nlm.nih.gov).

Hasil BLAST menunjukkan bahwa Begomovirus asal terung memiliki kemiripan dengan TYLCKaV yang berasal dari Thailand, Taiwan, dan Vietnam yang menginfeksi tanaman terung dan tomat. Empat isolat yaitu Bogor, Pati, Rembang, dan Bantul memiliki tingkat kemiripan yang sangat tinggi (>98\%) dengan TYLCKaV-[Tomato:Thailand] (AF511530); sedangkan isolat asal Bandung memiliki tingkat kemiripan yang lebih rendah dengan TYLCKaV-[Tomato:Thailand] (AF511530), yaitu 94.2\% (Tabel 1). Isolat Begomovirus asal Bogor, Bandung, Pati, Rembang, dan Bantul menunjukkan tingkat homologi atau kemiripan nukleotida yang sangat tinggi satu sama lain, yaitu berkisar 95\% sampai 99.8\% (Tabel 2). Fauquet et al.

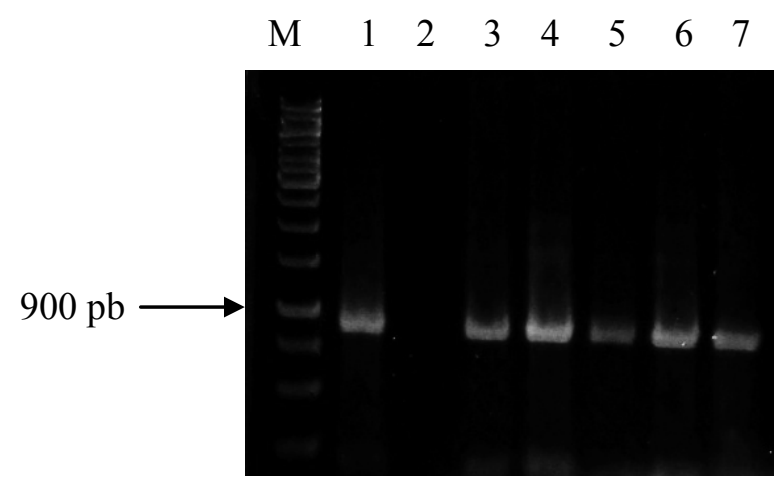

Gambar 2 Pita DNA hasil amplifikasi menggunakan teknik polymerase chain reaction dengan primer universal Begomovirus SPG1/SPG2. M, Penanda DNA (1kb); 1, Kontrol positif; 2, Kontrol negatif; 3 s.d 7 berturut-turut sampel dari Bogor, Bandung, Pati, Rembang, Bantul.

Tabel 1 Tingkat kesamaan sikuen nukleotida antara Begomovirus asal terung di Jawa dengan beberapa isolat Begomovirus yang dilaporkan dalam GenBank

\begin{tabular}{lccccccc}
\hline \multirow{2}{*}{ Isolat virus } & \multirow{2}{*}{ No aksesi } & Tanaman & \multicolumn{5}{c}{ Homologi (\%) antar isolat virus } \\
\cline { 5 - 7 } & inang & Bogor & Bandung & Pati & Rembang & Bantul \\
\hline $\begin{array}{l}\text { TYLCKaV } \\
\text { Thailand }\end{array}$ & AF511529 & Terung & 94.2 & 90.1 & 94.1 & 94.1 & 94.1 \\
$\begin{array}{l}\text { TYLCKaV } \\
\text { Thailand }\end{array}$ & AF511530 & Tomat & 98.8 & 94.2 & 98.9 & 98.7 & 98.7 \\
$\begin{array}{l}\text { TYLCKaV } \\
\text { Taiwan }\end{array}$ & DQ169054 & Tomat & 94.2 & 90.1 & 94.1 & 94.1 & 94.1 \\
$\begin{array}{l}\text { TYLCKaV } \\
\text { Vietnam }\end{array}$ & DQ641702 & Tomat & 94.2 & 90.1 & 94.1 & 94.1 & 94.1 \\
$\begin{array}{l}\text { TYLCV } \\
\text { Indonesia }\end{array}$ & AB162141 & Ageratum & 77.5 & 77.5 & 77.8 & 77.5 & 77.5 \\
$\begin{array}{l}\text { PepYLCV } \\
\text { Indonesia }\end{array}$ & GU382667 & Cabai & 41.3 & 41.3 & 41.1 & 41.3 & 39.1 \\
\hline
\end{tabular}


Tabel 2 Tingkat kesamaan sikuen nukleotida Begomovirus asal terung di Pulau Jawa

\begin{tabular}{lccccc}
\hline \multirow{2}{*}{ Isolat virus } & \multicolumn{5}{c}{ Homologi $(\%)$ isolat virus } \\
\cline { 2 - 6 } & 1 & 2 & 3 & 4 & 5 \\
\hline Bogor & - & 95.3 & 99.6 & 99.6 & 99.8 \\
Bandung & & - & 95.0 & 95.0 & 95.2 \\
Pati & & - & 99.5 & 99.5 \\
Rembang & & & - & 99.5 \\
Bantul & & & & - \\
\hline
\end{tabular}

(2005) menjelaskan bahwa apabila tingkat homologi sikuen genom A antar isolat Begomivirus mencapai lebih dari 90\% maka isolat-isolat tersebut merupakan satu spesies yang sama dalam genus Begomovirus. Oleh karena itu, Begomovirus asal Bogor, Bandung, Pati, Rembang, dan Bantul adalah satu spesies yang sama dengan TYLCKaV. Kelima isolat Begomovirus tersebut memiliki hubungan kekerabatan yang tidak terlalu dekat dengan isolat TYLCV yang menginfeksi Ageratum (77.5\%) (Kon et al. 2007) dan isolat Pepper yellow leaf curl virus (PYLCV) (39\%-41\%) (Hidayat et al. 2006; Priwiratama et al. 2012) yang menginfeksi cabai di Indonesia yang telah dilaporkan terlebih dahulu (Tabel 1).

Selain TYLCV dan ToLCNDV yang menyebabkan penyakit mosaik kuning pada terung berturut-turut di Thailand dan India, beberapa virus lain dilaporkan menjadi penyebab penyakit pada tanaman terung. Tomato spotted wilt virus (TSWV), Eggplant blister mosaic virus (EBMV) dan Eggplant mottled crinkle virus (EMCV) dilaporkan menginfeksi tanaman terung berturut-turut di Bulgaria, Irak, dan Israel (Dombrovsky et al. 2009; Al-ani et al. 2011; Dikova 2011). Identifikasi penyebab penyakit tanaman terung di Indonesia belum banyak dilakukan, pembuktian adanya infeksi TYLCKaV dari sampel tanaman yang berasal dari beberapa daerah di Jawa Barat dan Jawa Tengah merupakan laporan pertama adanya infeksi Begomovirus pada tanaman terung di Indonesia.

\section{DAFTAR PUSTAKA}

Al-ani RA, Adhab MA, Ismail KAH. 2011. Eggplant blister mottled virus (EBMV): a possible new Potyvirus characterized from Iraq. J Gen Mol Virol. 3(3):49-52. DOI: http://dx.doi.org/10.5897/JGMV.

Dikova B. 2011. Tomato spotted wilt virus on some medicinal and essential oil-bearing plants in Bulgaria. Bulg J Agric Sci. 17(3): 306-313.

Dombrovsky A, Pearlsman M, Iachman O, Antignus Y. 2009. Characterization of a new strain of Eggplant mottled crinckle virus (EMC) infecting eggplants in Israel. Phytoparasitica. 37(5):477-483. DOI: http://dx.doi.org/10.1007/s12600-0090058-z.

Doyle JJ, Doyle JJ. 1999. Isolation of plant DNA from fresh tissue. Focus. 12(1):13-15. Faquet CM, Mayo MA, Maniloff J, Desselberger U, Ball LA. 2005. Virus Taxonomy, VIII ${ }^{\text {th }}$ report of the ICTV. London (UK): Academic Press.

Green SK, Tsai WS, Shih SL. 2003. Molecular characterization of a new Begomovirus associated with Tomato yellow leaf curl and Eggplant yellow mosaic diseases in Thailand. Plant Dis. 87(4):446. DOI: http:// dx.doi.org/10.1094/PDIS.2003.87.5.598A.

Hidayat SH, Chatchawankanpanich O, Rusli E, Aidawati N. 2006. Begomovirus associated with pepper yellow leaf curl disease in West Java, Indonesia. J Mikrobiol Indones. 11(2):87-90.

Kon T, Kuwabara R, Hidayat SH, Ikegami M. 2007. A Begomovirus associated with 
Ageratum yellow vein disease in Indonesia: Evidence for natural recombination between Tomato leaf curl Java virus and Ageratum yellow vein virus-[Java]. Arch Virol. 152(6):1147-1157. DOI: http:// dx.doi.org/10.1007/s00705-006-0928-3.

Li R, Salih S, Hurtt S. 2004. Detection of geminiviruses in sweetpotato by polymerase chain reaction. Plant Dis. 88(12):1347-1351. DOI: http://dx.doi. org/10.1094/PDIS.2004.88.12.1347.

Pratap D, kashikar AR, Mukherjee SK. 2011. Molecular characterization and infectivity of a Tomato leaf curl New Delhi virus variant associated with newly emerging yellow mosaic disease of eggplant in India. Virol J. 8(1):305. DOI: http://dx.doi. org/10.1186/1743-422X-8-305.

Priwiratama H, Hidayat SH, Widodo. Pengaruh empat galur bakteri pemacu pertumbuhan tanaman dan waktu inokulasi virus terhadap keparahan penyakit daun keriting kuning cabai. J Fitopatol Indones. 8(1):1-8. DOI: 10.14692/jfi.8.1.1 